\title{
INFLUENCE OF SILICEOUS AND CALCAREOUS FLY-ASHES ON PROPERTIES OF CEMENT MORTARS
}

\author{
Gabriela Rutkowska ${ }^{1}$, Marek Chalecki' ${ }^{1}$ Piotr Wichowski' ${ }^{1}$, Joanna Żwirska' ${ }^{1}$, Bartosz Barszcz ${ }^{1}$ \\ Department of Civil Engineering, Warsaw University of Life Sciences (SGGW), Nowoursynowska 159, $02-776$ \\ Warszawa, Poland, e-mail: gabriela_rutkowska@sggw.pl, marek_chalecki@sggw.pl, piotr_wichowski@ \\ @sggw.pl
}

Received: 2016.05 .18 Accepted: 2016.08.08 Published: 2016.09 .20

\begin{abstract}
Care of the environment in accordance with the principles of sustainable development introduces the possibility and need for waste recycling. Construction and building industries have the greatest potential for reuse of waste. The article presents the results of investigations of cement mortars - tests of compressive and tensile strength after 28 and 56 days of curing - for normative mortars and mortars containing fly ashes calcareous and siliceous ash - in their composition. To make the samples, the Portland cement CEM I 32,5 R, 42,5R and natural aggregate with graining of $0-2 \mathrm{~mm}$ were used. Concrete with siliceous and calcareous admixtures was made in six lots where the ash was added in the quantity of $2 \%, 5 \%, 10 \%$ of the cement mass or the $2 \%, 5 \%$, $10 \%$ of cement was replaced by ashes. After the tests, it was stated that the siliceous fly-ash admixture increases the compressive and bending strength in comparison to the mortars with the calcareous ash admixtures.
\end{abstract}

Keywords: cement mortar, fly-ashes, strength of materials

\section{INTRODUCTION}

Care of the environment in accordance with the principles of sustainable development and the perspective of depletion of mineral fuels influences the policy of European Union aiming at the promotion of a new approach to the problem of use of renewable energy sources and dynamic development trends in the states - members of the European Union. The introduction of innovative solutions within a framework of the strategy "Europe 2020" encompasses also energy sector. Apart from conventional fuels, successful attempts of biomass combustion are observed [Deja 2012, Golec 2007, Rutkowska 2014]. The combustion of by-products arising as a result of coal combustion have been disposed for many years on the earth surface or underground in mines. However, this form of fly-ash recycling results in degradation of surface and underground water due to the penetration of components from the wastes in the area of their disposal [Rosik-Dulewska and
Karwaczyńska 2008]. Hence, investigations are necessary to encompass i.a. the evaluation of possibilities of application of fly-ashes in the recycling of materials used in the building industry.

The idea of application of fly-ash in the production of concrete and cement mortars is not new. Even the ancient Romans discovered that the concrete properties can be improved by additions of volcanic ashes. Fly-ashes were applied in the USA in the 1930's [ACI 1996, Comões 2002, Joshi 1997, Malhotra and Wesche 1991]. In Poland and Europe, the siliceous fly-ashes have wide application in the cement and concrete technology [Giergiczny 2013]. Present among the ingredients of concrete, cement and cement mortar, the fly-ashes cause that the quantity of the applied cement clinker is lower and, in turn, it increases savings in mineral fuels and natural materials as well as reduction of the emitted carbon dioxide and environment pollution [Deja 2012]. It is an important problem because in the production of cement a lot of energy is used and there is ca. 
1.6 billion of tones of $\mathrm{CO}_{2}$ emitted per year [Elahi 2010]. Wide application of the fly-ash in the building industry is mainly due to: its high fineness, close to this of the cement, its chemical constitution and phase composition, close to those of clay materials, as well as its reactivity, particularly the pozzolanic activity [Giergiczny 2013].

The paper presents the results of investigations which were aimed to analyze how the siliceous and calcareous fly-ashes added to cement mortars influence the technical properties of the mortar.

\section{METHODOLOGY OF INVESTIGATIONS}

The research and design procedures are based on the directives contained in the currently binding Polish building standards. The tests were performed in the Laboratory of Building Constructions of Warsaw University of Life Sciences.

The cement mortar samples being tested were calculated according to the standard PNB- 14501:1990 "Ordinary building mortars". To perform the tests, it was assumed a mortar composition according to the standard. To prepare the samples, ordinary aggregate with the graining 0-2 mm (sand) and Portland cement 32.5 without admixtures were used.

To investigate the bending strength, the samples of the size $40 \times 40 \times 160 \mathrm{~mm}$ were used. The investigations were performed according to the directives contained in the standard PN-EN 101511:2001. The investigations of the compressive strength were performed according to the standard PN-EN 1015-11:2001 on the halves of the beam samples remaining from the performed bending strength tests. The samples were subjected to the tests in a testing machine with special pads, after 28 and 56 days of the concrete curing period.

\section{FLY-ASHES FOR CONCRETES}

Grains of fly-ash have a diameter from 1 to $150 \mu \mathrm{m}$ - it is close to the cement grain diameter falling into the range 7-12 $\mu \mathrm{m}$ [Joshi 1997]. They usually have a spheroid shape, but they can also be prismatic and irregular. They are characterized by high fineness and contain ca. $80 \%$ of glass. The Blaine specific surface is equal $250-550 \mathrm{~m}^{2} /$ $\mathrm{kg}$ [Alonso 1991]. According to Malhotra and Ramezanianpour [Malhotra], the graining and the surface of the fly-ash is not connected to its source of orgin. The grains bigger than $125 \mu \mathrm{m}$ have high porosity. It is due to the higher share of coal. According Alonso and Wesche [Alonso 1991], the pozzolanic activity of the fly-ashes depends on the silica content.

Taking the chemical properties into consideration, the siliceous fly-ashes contain mostly the reactive silica $\left(\mathrm{SiO}_{2}\right)$ and aluminum oxide $\left(\mathrm{Al}_{2} \mathrm{O}_{3}\right)$; they have pozzolanic properties - they react with calcium hydroxide in the presence of water, giving hydrated calcium aluminates and silicates. They also contain iron oxide $\left(\mathrm{Fe}_{2} \mathrm{O}_{3}\right)$ and other compounds. The calcareous fly-ashes, however, have hydraulic and/or pozzolanic properties and contain mainly the reactive calcium oxide $(\mathrm{CaO})$, reactive silica $\left(\mathrm{SiO}_{2}\right)$ and aluminium oxide $\left(\mathrm{Al}_{2} \mathrm{O}_{3}\right)$ [ACI 1996, Malhotra and Giergiczny 2013].

The fly-ash, applied in the investigations, is a very fine ash with hydraulic and/or pozzolanic properties. Table 1 shows the composition of flyashes used in the investigations.

Figure 1 shows fly-ashes with various level of ignition loss: a) ash with ca. $2.2 \%$ of ignition loss, b) ash with ca. $17.9 \%$ of ignition loss.

Table 1. Chemical composition of fly-ash [research report 2014]

\begin{tabular}{|c|c|c|}
\hline Contents & $\begin{array}{c}\text { Calcareous fly-ash } \\
{[\% \text { of mass }]}\end{array}$ & $\begin{array}{c}\text { Siliceous fly-ash } \\
{[\% \text { of mass }]}\end{array}$ \\
\hline Ignition loss & 2.1 & 4.05 \\
\hline $\mathrm{SiO}_{2}$ & 42.8 & 50.5 \\
\hline $\mathrm{Al}_{2} \mathrm{O}_{3}$ & 20.5 & 21.8 \\
\hline $\mathrm{CaO}$ & 22.5 & 4.1 \\
\hline $\mathrm{MgO}$ & 0.9 & 2.5 \\
\hline $\mathrm{SO}_{3}$ & 4.3 & 0.7 \\
\hline $\mathrm{Na}_{2} \mathrm{O}$ & 0.1 & 1.21 \\
\hline $\mathrm{K}_{2} \mathrm{O}$ & 0.2 & 3.02 \\
\hline $\mathrm{CaO}$ free & 4.1 & - \\
\hline
\end{tabular}




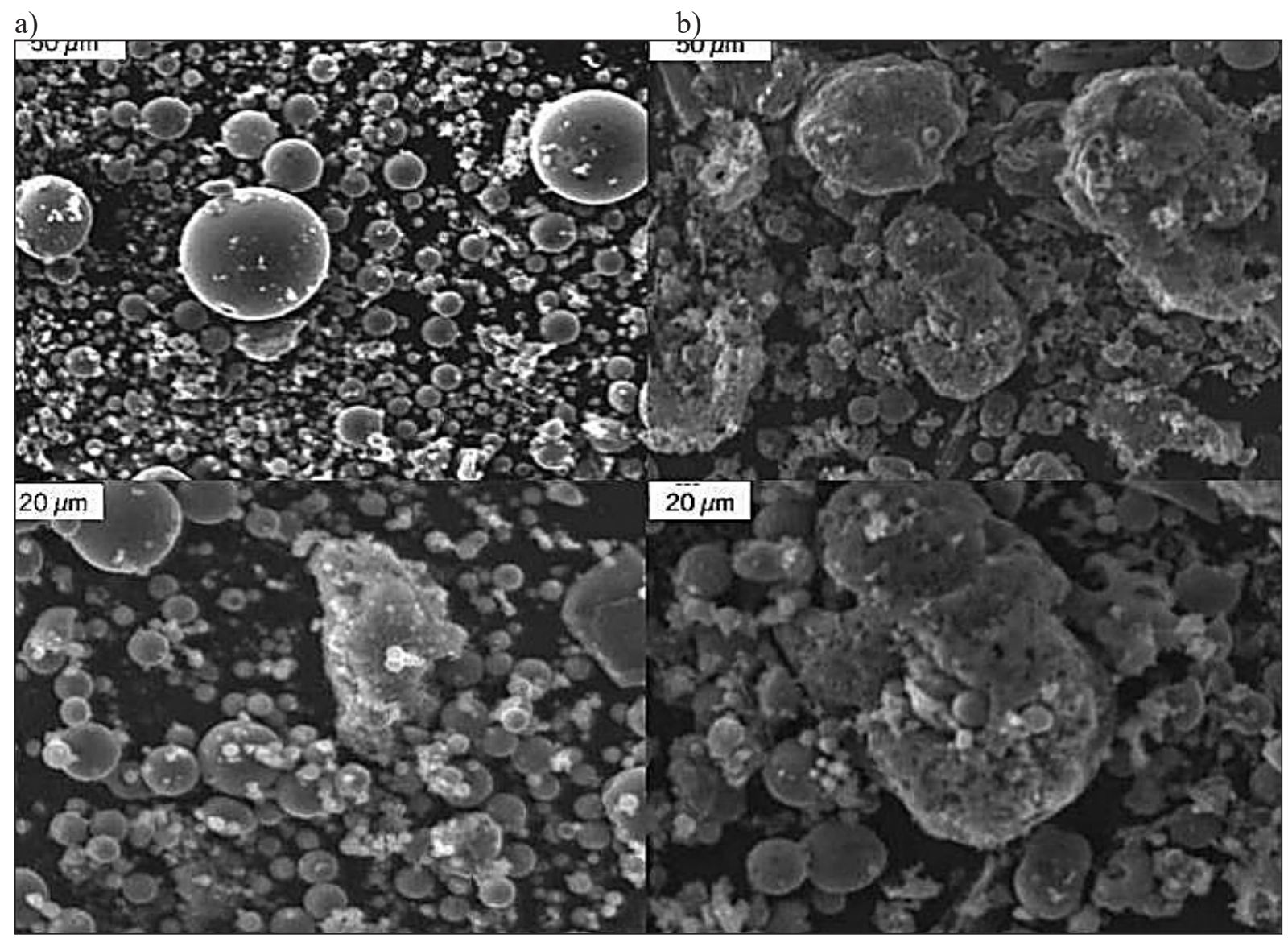

Figure 1. Grains of fly-ashes with various level of ignition loss [Giergiczny 2007]:

a) ash with ca. $2.2 \%$ of ignition loss, b) ash with ca. $17.9 \%$ of ignition loss

\section{LABORATORY TESTS}

To make the cement mortar, the $1^{\text {st }}$ type Portland cement without admixtures (CEM I 32,5 R) was used (Cement Plant „Ożarów”, Poland). The fly-ashes used for the samples came from two thermal-electric power stations: Siekierki (Warsaw - siliceous fly-ash - Lafarge) and Bełchatów (calcareous fly-ash); they complied with the requirements given in the standard PN-EN 450$1+\mathrm{A} 1: 2009$ on the requirements for the fly-ashes applied in the concrete production.

The tests consisted in the comparison of features of cement mortars produced in the traditional way as well as the mortars containing the combustion by-products. To do this, three types of mortar samples were prepared:

1) without any admixtures,

2) with addition of the siliceous fly-ash,

3) with addition of the calcareous fly-ash.

Apart of this, for each type of the mortars 6 series were made - in the three of them the normative composition was doped by fly-ashes con- stituting 2, 5 and $10 \%$ of cement mass, in the remaining three of them 2,5 and $10 \%$ of the cement mass was removed and substituted by fly-ashes.

All of the mortars were prepared in the Laboratory of Building Constructions of the Faculty of Civil and Environmental Engineering of WULS. During the tests the compression and bending strength after 28 and 56 days of curing were investigated. To prepare the cement mortar samples, the normative sand CEN - Kwarcmix with graining $0-2 \mathrm{~mm}$ as well as the Portland cement CEM I 42,5 without admixtures, with density $3.1 \mathrm{~kg} / \mathrm{m}^{3}$ and early strength $\mathrm{R}$ were used. The composition of normative mortar was prepared according to the standard PN-EN 196-1:2006 for each of the three beam samples, according to the following proportions: 1 part of cement, 3 parts of normative sand, 0.5 part of water (water/cement ratio $\mathrm{W} / \mathrm{C}=0.5$ ). Due to this, the normative mortar to make three beam samples (1 mould) contains of:

- $450 \pm 2 \mathrm{~g}$ of cement,

- $1350 \pm 5 \mathrm{~g}$ of normative sand, according to the standard PN-EN 196-1:2006,

- $225 \pm 1 \mathrm{~cm}^{3}$ of water. 
Table 2. Composition of a cement mortar modified with calcareous and siliceous fly-ashes

\begin{tabular}{|c|c|c|c|c|c|}
\hline \multirow[b]{2}{*}{ Sample marking } & \multicolumn{4}{|c|}{ Quantity of compounds [g] } & \multirow[b]{2}{*}{ water/cement ratio } \\
\hline & cement & aggregate & water & $\begin{array}{l}\text { calcareous / siliceous } \\
\text { fly-ash }\end{array}$ & \\
\hline Normative mortar & 450 & 1350 & 225 & 0 & 0.500 \\
\hline$+2 \%$ & 450 & 1350 & 225 & 9 & 0.500 \\
\hline$+5 \%$ & 450 & 1350 & 225 & 22.5 & 0.500 \\
\hline$+10 \%$ & 450 & 1350 & 225 & 45 & 0.500 \\
\hline$-2 \%$ & 441 & 1350 & 225 & 9 & 0.510 \\
\hline$-5 \%$ & 427.5 & 1350 & 225 & 22.5 & 0.526 \\
\hline$-10 \%$ & 405 & 1350 & 225 & 45 & 0.556 \\
\hline
\end{tabular}

Table 2 presents the composition of individual samples.

\section{TEST RESULTS - COMPRESSIVE AND BENDING STRENGTH}

To determine the bending strength of the beam samples made of the cement mortar, the testing machine with a breaking set (Figure 2) has been used. The sample being tested was placed on the two lower supports (rollers), whereas the upper support was imposed by a load evoking the sample break. The pressure was increased evenly by $50 \pm 10 \mathrm{~N} / \mathrm{s}$, till the moment in which the sample is broken [PN-EN 1015-11:2001].

The compressive strength $(f, \mathrm{MPa})$ is calculated from the formula

$$
f=1,5 \frac{F \cdot l}{b \cdot d^{2}}[M P a]
$$

where: $f$-compressive strength

$F$ - maximum loading force $[\mathrm{N}]$

$I$ - distance between the lower supports [mm]

$b$ - sample width [mm]

$d$-sample height [mm].

The compressive strength tests have been carried out on the halves of the beam samples, broken in the bending strength test (Figure 3). The test has been performed in the testing machine with a special pad. The surfaces of the samples were evenly imposed by the load increasing with velocity $2400 \pm 200 \mathrm{~N} / \mathrm{s}$, till the sample failure. The compressive strength is calculated according to the formula [PN-EN 1015-11:2001]

$$
f_{c}=\frac{F}{A}[M P a]
$$

where: $f_{c}$ - compressive strength

$F$ - maximum load $[\mathrm{N}]$

$A$ - area of the compressed surface $\left[\mathrm{mm}^{2}\right]$.

Tables 3-6 present the results of the compressive and bending strength tests for the cement mortar samples. The tests were performed after 28 and 56 days of mortar curing.

The results obtained from the tests show (Figures 3-6) that the compressive strength of the cement mortars exceeds the value predicted in the standards. The mortars without admixtures were the reference samples. For the siliceous ash series the average compressive strength of the reference samples after 28 days of curing was equal 44.22 $\mathrm{MPa}$, for the calcareous ash series $-38.44 \mathrm{MPa}$; after 56 days of curing, it was equal $55.52 \mathrm{MPa}$ and $44.90 \mathrm{MPa}$, respectively. Along with the increase of the siliceous ash content, the mortar's strength increased. For the mortars doped with the siliceous fly-ash constituting $2 \%$ of content, the average strength was equal $47.14 \mathrm{MPa}$, however, for the mortar sample with the $5 \%$ of ash content it was equal $48.44 \mathrm{MPa}$. The samples with the $10 \%$ of siliceous ash content reached lower compressive strength - equal to $45.57 \mathrm{MPa}$. If the cement was replaced by the fly-ash, the compressive strength decreases along with the increase of the ash amount. After 56 days of curing, next measurements were performed and they showed that the compressive strength increased. The mortars doped with the siliceous fly-ash constituting $2 \%$ of content showed the strength increase from 47.14 to $59.90 \mathrm{MPa}$. For the mortar samples doped with the $5 \%$ of ash content the strength increased to $60.47 \mathrm{MPa}$ whereas for those doped with the $10 \%$ of ash content - to $64.59 \mathrm{MPa}$ and it was the 
a)

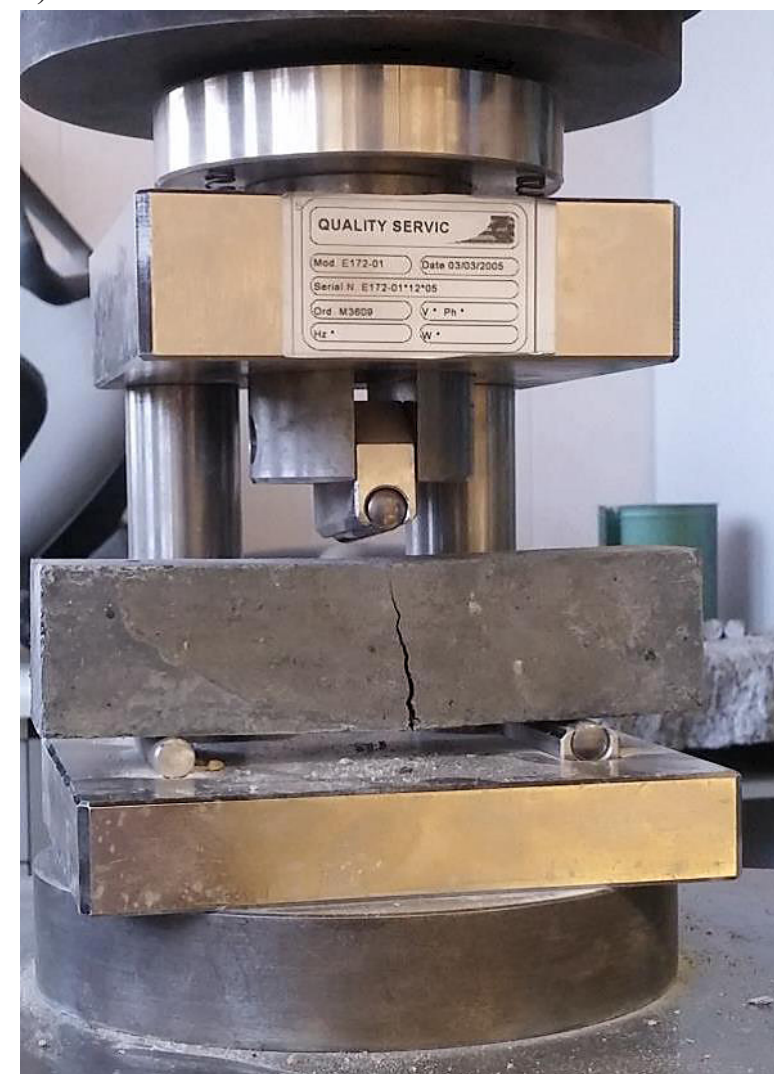

b)

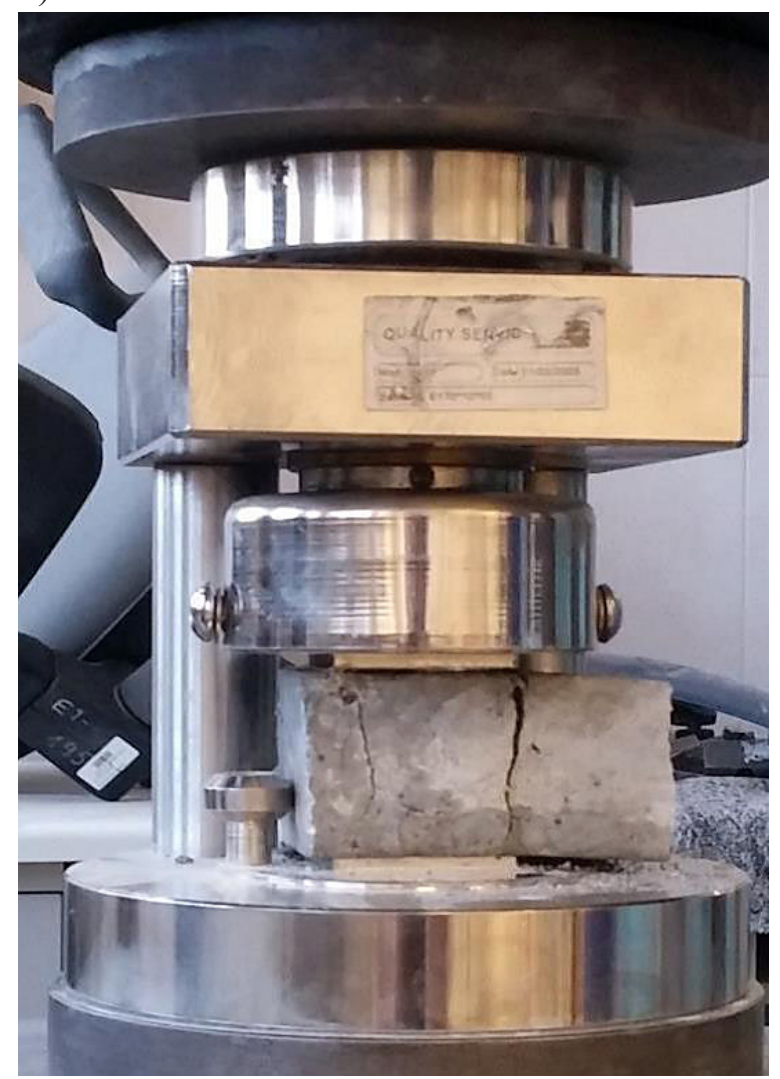

Fig. 2. Samples placed in the testing machine: a) bending strength test, b) compressive strength test

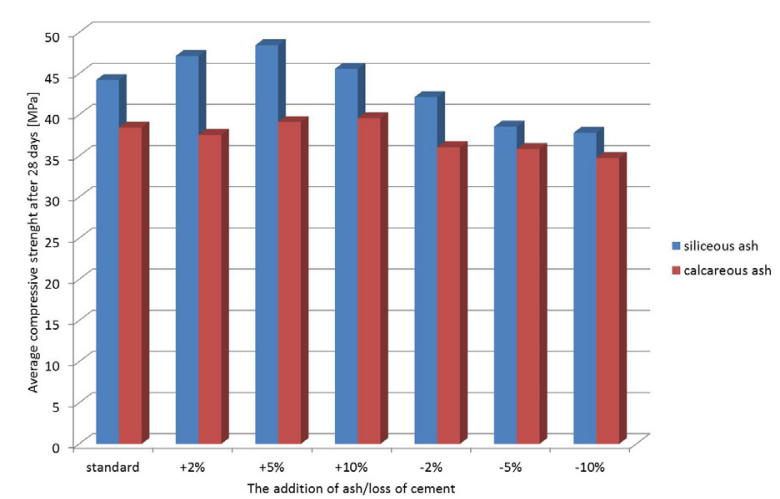

Figure 3. The average compressive strength after 28 days

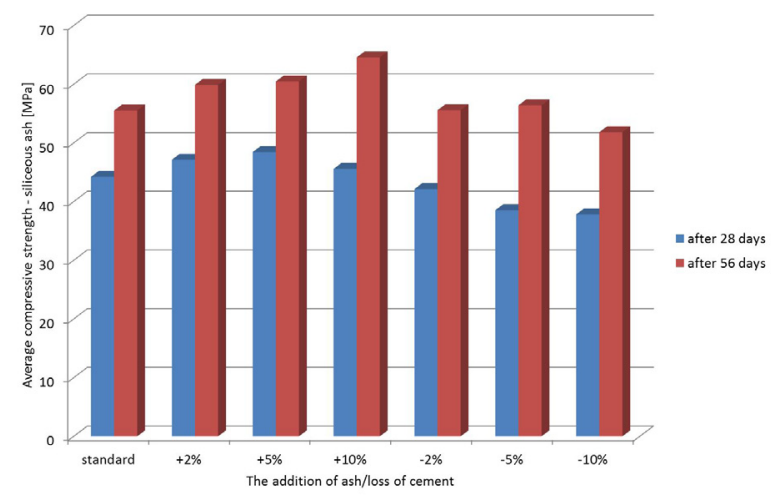

Figure 5. The average strength of concrete with siliceous ash sfter 28 and 56 days

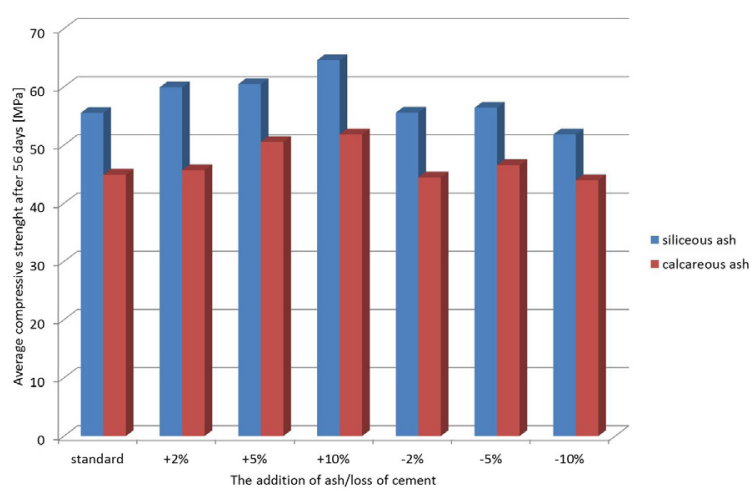

Figure 4. The average compressive strength after 56 days

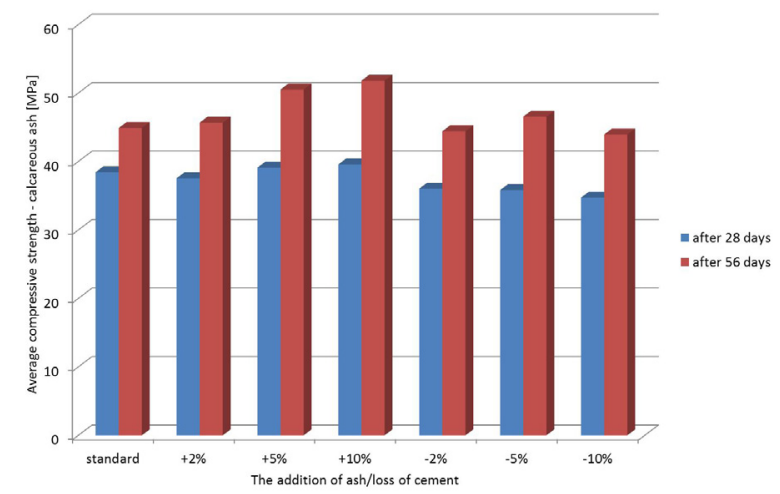

Figure 6. The average strength of concrete with calcareous ash sfter 28 and 56 days 
Table 3. Results of the compressive and bending strength tests after 28 days of curing of the mortar with siliceous fly-ashes

\begin{tabular}{|c|c|c|c|c|c|c|c|c|c|}
\hline \multirow{2}{*}{$\begin{array}{l}\text { Sample } \\
\text { marking }\end{array}$} & \multirow[b]{2}{*}{$\begin{array}{c}\text { Mass } \\
{[\mathrm{kg}]}\end{array}$} & \multicolumn{3}{|c|}{ Sample sizes } & \multirow{2}{*}{$\begin{array}{c}\text { Bending } \\
\text { strength } \\
\text { [MPa] }\end{array}$} & \multirow{2}{*}{$\begin{array}{c}\text { Average } \\
\text { bending } \\
\text { strength } \\
\text { [MPa] }\end{array}$} & \multirow{2}{*}{\multicolumn{2}{|c|}{$\begin{array}{c}\text { Compressive strength } \\
{[\mathrm{MPa}]}\end{array}$}} & \multirow{2}{*}{$\begin{array}{c}\text { Average } \\
\text { compressive } \\
\text { strength } \\
\text { [MPa] }\end{array}$} \\
\hline & & $\begin{array}{c}\text { height } \\
{[\mathrm{mm}]}\end{array}$ & $\begin{array}{l}\text { width } \\
{[\mathrm{mm}]}\end{array}$ & $\begin{array}{c}\text { length } \\
{[\mathrm{mm}]}\end{array}$ & & & & & \\
\hline \multirow{3}{*}{$\begin{array}{l}\text { Norma-tive } \\
\text { mortar }\end{array}$} & 0.589 & 40.81 & 40.29 & 159.93 & 7.60 & \multirow{3}{*}{7.95} & 43.75 & 44.38 & \multirow{3}{*}{44.22} \\
\hline & 0.577 & 41.56 & 40.15 & 159.58 & 8.44 & & 44.69 & 43.75 & \\
\hline & 0.586 & 40.90 & 40.09 & 159.44 & 7.83 & & 44.38 & 44.38 & \\
\hline \multirow{3}{*}{$+2 \%$} & 0.590 & 41.79 & 40.09 & 159.98 & 8.57 & \multirow{3}{*}{8.56} & 46.88 & 48.13 & \multirow{3}{*}{47.14} \\
\hline & 0.595 & 41.55 & 40.41 & 159.76 & 8.60 & & 47.81 & 46.88 & \\
\hline & 0.597 & 41.86 & 40.17 & 159.61 & 8.52 & & 46.25 & 46.88 & \\
\hline \multirow{3}{*}{$+5 \%$} & 0.593 & 41.44 & 40.58 & 159.78 & 8.83 & \multirow{3}{*}{9.01} & 48.13 & 48.75 & \multirow{3}{*}{48.44} \\
\hline & 0.588 & 40.76 & 39.92 & 160.09 & 9.27 & & 48.75 & 48.13 & \\
\hline & 0.589 & 40.90 & 40.21 & 159.91 & 8.92 & & 48.44 & 48.44 & \\
\hline \multirow{3}{*}{$+10 \%$} & 0.612 & 41.72 & 40.51 & 160.07 & 8.72 & \multirow{3}{*}{8.71} & 45.31 & 46.25 & \multirow{3}{*}{45.57} \\
\hline & 0.605 & 42.07 & 40.16 & 160.19 & 8.44 & & 44.69 & 45.31 & \\
\hline & 0.601 & 41.71 & 39.87 & 160.04 & 8.97 & & 46.25 & 45.63 & \\
\hline \multirow{3}{*}{$-2 \%$} & 0.591 & 42.03 & 40.11 & 159.81 & 7.41 & \multirow{3}{*}{7.88} & 42.50 & 42.19 & \multirow{3}{*}{42.14} \\
\hline & 0.587 & 41.32 & 40.25 & 159.89 & 8.19 & & 41.88 & 42.19 & \\
\hline & 0.588 & 41.50 & 40.08 & 159.89 & 8.04 & & 42.19 & 41.88 & \\
\hline \multirow{3}{*}{$-5 \%$} & 0.590 & 41.61 & 40.02 & 159.94 & 8.23 & \multirow{3}{*}{8.39} & 38.75 & 38.44 & \multirow{3}{*}{38.54} \\
\hline & 0.593 & 40.85 & 40.50 & 160.07 & 8.32 & & 38.4 & 38.75 & \\
\hline & 0.584 & 40.34 & 40.03 & 160.33 & 8.64 & & 38.13 & 38.75 & \\
\hline \multirow{3}{*}{$-10 \%$} & 0.599 & 41.32 & 40.55 & 159.86 & 8.02 & \multirow{3}{*}{8.25} & 37.50 & 37.81 & \multirow{3}{*}{37.81} \\
\hline & 0.582 & 40.70 & 39.89 & 159.80 & 8.17 & & 37.50 & 38.13 & \\
\hline & 0.588 & 41.59 & 40.46 & 159.91 & 8.57 & & 38.13 & 37.81 & \\
\hline
\end{tabular}

Table 4. Results of the compressive and bending strength tests after 56 days of curing of the mortar with siliceous fly-ashes

\begin{tabular}{|c|c|c|c|c|c|c|c|c|c|}
\hline \multirow{2}{*}{$\begin{array}{l}\text { Sample } \\
\text { marking }\end{array}$} & \multirow{2}{*}{$\begin{array}{c}\text { Mass } \\
{[\mathrm{kg}]}\end{array}$} & \multicolumn{3}{|c|}{ Sample sizes } & \multirow{2}{*}{$\begin{array}{c}\text { Bending } \\
\text { strength } \\
\text { [MPa] }\end{array}$} & \multirow{2}{*}{$\begin{array}{c}\text { Average } \\
\text { bending } \\
\text { strength } \\
\text { [MPa] }\end{array}$} & \multirow{2}{*}{\multicolumn{2}{|c|}{$\begin{array}{c}\text { Compressive strength } \\
{[\mathrm{MPa}]}\end{array}$}} & \multirow{2}{*}{$\begin{array}{l}\text { Average } \\
\text { compressive } \\
\text { strength } \\
\text { [MPa] }\end{array}$} \\
\hline & & $\begin{array}{c}\text { height } \\
{[\mathrm{mm}]}\end{array}$ & $\begin{array}{l}\text { width } \\
\text { [mm] }\end{array}$ & $\begin{array}{c}\text { length } \\
{[\mathrm{mm}]}\end{array}$ & & & & & \\
\hline \multirow{3}{*}{$\begin{array}{l}\text { Norma-tive } \\
\text { mortar }\end{array}$} & 0.581 & 40.88 & 41.07 & 160.42 & 7.87 & \multirow{3}{*}{8.64} & 55.63 & 55.31 & \multirow{3}{*}{55.52} \\
\hline & 0.576 & 40.91 & 39.99 & 159.83 & 9.41 & & 56.25 & 55.31 & \\
\hline & 0.580 & 40.36 & 41.57 & 160.10 & 8.64 & & 55.00 & 55.63 & \\
\hline \multirow{3}{*}{$+2 \%$} & 0.586 & 41.25 & 39.95 & 159.73 & 8.83 & \multirow{3}{*}{8.79} & 58.13 & 60.31 & \multirow{3}{*}{59.90} \\
\hline & 0.596 & 40.60 & 41.51 & 159.65 & 8.77 & & 59.69 & 61.88 & \\
\hline & 0.591 & 41.50 & 40.68 & 160.04 & 8.78 & & 59.06 & 60.31 & \\
\hline \multirow{3}{*}{$+5 \%$} & 0.600 & 40.76 & 40.49 & 160.49 & 9.37 & \multirow{3}{*}{8.22} & 60.00 & 58.75 & \multirow{3}{*}{60.47} \\
\hline & 0.591 & 41.01 & 40.20 & 160.00 & 9.98 & & 61.25 & 60.63 & \\
\hline & 0.598 & 42.75 & 40.54 & 161.04 & 8.30 & & 60.94 & 61.25 & \\
\hline \multirow{3}{*}{$+10 \%$} & 0.597 & 40.95 & 40.08 & 159.86 & 9.82 & \multirow{3}{*}{9.50} & 64.69 & 66.25 & \multirow{3}{*}{64.58} \\
\hline & 0.596 & 42.99 & 40.19 & 160.32 & 8.68 & & 63.44 & 65.00 & \\
\hline & 0.607 & 40.65 & 40.00 & 160.07 & 9.99 & & 63.13 & 65.00 & \\
\hline \multirow{3}{*}{$-2 \%$} & 0.591 & 40.63 & 40.70 & 159.55 & 8.71 & \multirow{3}{*}{8.69} & 54.38 & 55.00 & \multirow{3}{*}{55.57} \\
\hline & 0.608 & 40.33 & 43.00 & 160.02 & 8.69 & & 55.94 & 56.25 & \\
\hline & 0.598 & 41.85 & 40.45 & 159.89 & 8.68 & & 56.25 & 55.63 & \\
\hline \multirow{3}{*}{$-5 \%$} & 0.599 & 40.83 & 40.14 & 160.49 & 9.41 & \multirow{3}{*}{9.35} & 55.00 & 56.25 & \multirow{3}{*}{56.41} \\
\hline & 0.591 & 41.45 & 40.08 & 160.97 & 9.37 & & 56.88 & 57.50 & \\
\hline & 0.600 & 41.04 & 40.30 & 160.87 & 9.28 & & 56.88 & 55.94 & \\
\hline \multirow{3}{*}{$-10 \%$} & 0.586 & 41.38 & 39.96 & 159.85 & 8.77 & \multirow{3}{*}{8.87} & 51.25 & 51.25 & \multirow{3}{*}{51.82} \\
\hline & 0.591 & 40.85 & 40.70 & 159.73 & 9.06 & & 52.19 & 51.25 & \\
\hline & 0.595 & 41.03 & 40.55 & 159.60 & 8.79 & & 51.22 & 53.75 & \\
\hline
\end{tabular}


Table 5. Results of the compressive and bending strength tests after 28 days of curing of the mortar with calcareous fly-ashes

\begin{tabular}{|c|c|c|c|c|c|c|c|c|c|}
\hline \multirow{2}{*}{$\begin{array}{l}\text { Sample } \\
\text { marking }\end{array}$} & \multirow{2}{*}{$\begin{array}{c}\text { Mass } \\
{[\mathrm{kg}]}\end{array}$} & \multicolumn{3}{|c|}{ Sample sizes } & \multirow{2}{*}{$\begin{array}{c}\text { Bending } \\
\text { strength } \\
\text { [MPa] }\end{array}$} & \multirow{2}{*}{$\begin{array}{c}\text { Average } \\
\text { bending } \\
\text { strength } \\
\text { [MPa] }\end{array}$} & \multirow{2}{*}{\multicolumn{2}{|c|}{$\begin{array}{c}\text { Compressive strength } \\
{[\mathrm{MPa}]}\end{array}$}} & \multirow{2}{*}{$\begin{array}{c}\text { Average } \\
\text { compressive } \\
\text { strength } \\
\text { [MPa] }\end{array}$} \\
\hline & & $\begin{array}{l}\text { height } \\
{[\mathrm{mm}]}\end{array}$ & $\begin{array}{l}\text { width } \\
{[\mathrm{mm}]}\end{array}$ & $\begin{array}{c}\text { length } \\
{[\mathrm{mm}]}\end{array}$ & & & & & \\
\hline \multirow{3}{*}{$\begin{array}{c}\text { Norma-tive } \\
\text { mortar }\end{array}$} & 0.590 & 39.60 & 41.13 & 160.06 & 8.37 & \multirow{3}{*}{8.15} & 38.75 & 38.44 & \multirow{3}{*}{38.44} \\
\hline & 0.591 & 39.68 & 41.41 & 159.87 & 8.05 & & 38.13 & 39.06 & \\
\hline & 0.591 & 39.78 & 41.27 & 160.17 & 8.04 & & 38.13 & 38.13 & \\
\hline \multirow{3}{*}{$+2 \%$} & 0.585 & 40.14 & 41.16 & 160.07 & 7.69 & \multirow{3}{*}{7.79} & 37.50 & 36.88 & \multirow{3}{*}{37.55} \\
\hline & 0.584 & 39.89 & 41.24 & 159.96 & 7.66 & & 38.13 & 36.25 & \\
\hline & 0.592 & 40.22 & 41.64 & 159.96 & 8.02 & & 40.31 & 36.25 & \\
\hline \multirow{3}{*}{$+5 \%$} & 0.569 & 40.26 & 40.34 & 159.85 & 8.26 & \multirow{3}{*}{8.23} & 39.06 & 39.06 & \multirow{3}{*}{39.11} \\
\hline & 0.574 & 39.78 & 40.98 & 159.96 & 8.33 & & 40.31 & 39.06 & \\
\hline & 0.577 & 40.07 & 40.33 & 159.53 & 8.11 & & 38.13 & 39.06 & \\
\hline \multirow{3}{*}{$+10 \%$} & 0.573 & 39.92 & 40.3 & 159.76 & 7.82 & \multirow{3}{*}{7.84} & 39.38 & 39.69 & \multirow{3}{*}{39.58} \\
\hline & 0.578 & 40.10 & 41.25 & 159.66 & 7.91 & & 39.06 & 40.00 & \\
\hline & 0.572 & 40.03 & 40.87 & 159.33 & 7.79 & & 39.38 & 40.00 & \\
\hline \multirow{3}{*}{$-2 \%$} & 0.581 & 39.93 & 40.33 & 159.49 & 7.21 & \multirow{3}{*}{7.23} & 35.94 & 36.25 & \multirow{3}{*}{36.04} \\
\hline & 0.577 & 39.84 & 40.42 & 159.64 & 7.25 & & 36.25 & 35.94 & \\
\hline & 0.579 & 39.95 & 40.89 & 159.87 & 7.36 & & 36.25 & 35.66 & \\
\hline \multirow{3}{*}{$-5 \%$} & 0.567 & 40.00 & 40.81 & 159.98 & 6.66 & \multirow{3}{*}{6.81} & 36.56 & 35.66 & \multirow{3}{*}{35.83} \\
\hline & 0.570 & 40.34 & 40.49 & 160.21 & 6.83 & & 36.25 & 35.66 & \\
\hline & 0.570 & 40.50 & 40.24 & 159.75 & 6.93 & & 35.94 & 35.00 & \\
\hline \multirow{3}{*}{$-10 \%$} & 0.568 & 40.18 & 40.12 & 159.56 & 7.18 & \multirow{3}{*}{7.46} & 35.63 & 35.94 & \multirow{3}{*}{34.79} \\
\hline & 0.569 & 39.90 & 40.57 & 159.67 & 7.90 & & 35.00 & 34.38 & \\
\hline & 0.563 & 40.16 & 40.66 & 159.86 & 7.32 & & 32.81 & 35.00 & \\
\hline
\end{tabular}

Table 6. Results of the compressive and bending strength tests after 56 days of curing of the mortar with calcareous fly-ashes

\begin{tabular}{|c|c|c|c|c|c|c|c|c|c|}
\hline \multirow{5}{*}{$\begin{array}{c}\text { Sample } \\
\text { marking }\end{array}$} & \multirow{3}{*}{$\begin{array}{c}\text { Mass } \\
{[\mathrm{kg}]} \\
0.583\end{array}$} & \multicolumn{3}{|c|}{ Sample sizes } & \multirow{3}{*}{$\begin{array}{c}\text { Bending } \\
\text { strength } \\
\text { [MPa] }\end{array}$} & \multirow{2}{*}{$\begin{array}{c}\text { Average } \\
\text { bending } \\
\text { strength } \\
\text { [MPa] }\end{array}$} & \multirow{2}{*}{\multicolumn{2}{|c|}{$\begin{array}{c}\text { Compressive strength } \\
{[\mathrm{MPa}]}\end{array}$}} & \multirow{2}{*}{$\begin{array}{l}\text { Average } \\
\text { compressive } \\
\text { strength } \\
\text { [MPa] }\end{array}$} \\
\hline & & \multirow{2}{*}{ 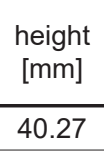 } & \multirow{2}{*}{$\begin{array}{l}\text { width } \\
{[\mathrm{mm}]}\end{array}$} & \multirow{2}{*}{$\begin{array}{c}\begin{array}{c}\text { length } \\
{[\mathrm{mm}]}\end{array} \\
159.84\end{array}$} & & & & & \\
\hline & & & & & & \multirow{3}{*}{8.82} & 42.50 & 47.81 & \multirow{3}{*}{44.90} \\
\hline & 0.587 & 40.29 & 41.49 & 160.12 & 8.91 & & 45.00 & 45.63 & \\
\hline & 0.580 & 39.96 & 41.54 & 160.31 & 8.59 & & 44.69 & 43.75 & \\
\hline \multirow{3}{*}{$+2 \%$} & 0.574 & 40.31 & 41.54 & 160.02 & 8.65 & \multirow{3}{*}{8.79} & 46.88 & 46.25 & \multirow{3}{*}{45.68} \\
\hline & 0.576 & 40.05 & 40.85 & 160.04 & 8.70 & & 45.94 & 45.00 & \\
\hline & 0.574 & 40.41 & 40.79 & 160.09 & 9.02 & & 45.63 & 40.38 & \\
\hline \multirow{3}{*}{$+5 \%$} & 0.582 & 40.40 & 40.84 & 160.42 & 8.55 & \multirow{3}{*}{8.87} & 51.56 & 50.69 & \multirow{3}{*}{50.52} \\
\hline & 0.580 & 40.05 & 41.21 & 160.03 & 9.08 & & 50.63 & 50.00 & \\
\hline & 0.584 & 40.37 & 41.05 & 159.89 & 8.97 & & 50.00 & 50.31 & \\
\hline \multirow{3}{*}{$+10 \%$} & 0.577 & 39.91 & 40.92 & 159.97 & 8.52 & \multirow{3}{*}{8.82} & 51.25 & 50.94 & \multirow{3}{*}{51.82} \\
\hline & 0.571 & 40.22 & 40.86 & 160.13 & 8.62 & & 51.88 & 52.19 & \\
\hline & 0.586 & 40.53 & 41.10 & 159.97 & 9.33 & & 52.19 & 52.50 & \\
\hline \multirow{3}{*}{$-2 \%$} & 0.574 & 40.32 & 40.86 & 159.93 & 8.96 & \multirow{3}{*}{8.12} & 42.81 & 43.13 & \multirow{3}{*}{44.43} \\
\hline & 0.570 & 40.26 & 40.50 & 160.12 & 8.00 & & 44.69 & 45.63 & \\
\hline & 0.570 & 40.24 & 40.54 & 159.85 & 8.00 & & 45.00 & 45.31 & \\
\hline \multirow{3}{*}{$-5 \%$} & 0.570 & 39.95 & 40.31 & 159.98 & 8.39 & \multirow{3}{*}{8.44} & 46.88 & 47.50 & \multirow{3}{*}{46.56} \\
\hline & 0.572 & 40.44 & 40.48 & 160.10 & 8.61 & & 46.25 & 46.25 & \\
\hline & 0.574 & 40.15 & 40.35 & 160.15 & 8.30 & & 46.88 & 45.63 & \\
\hline \multirow{3}{*}{$-10 \%$} & 0.578 & 39.97 & 41.10 & 160.17 & 8.68 & \multirow{3}{*}{9.06} & 43.75 & 44.69 & \multirow{3}{*}{43.96} \\
\hline & 0.585 & 40.30 & 41.02 & 160.80 & 9.46 & & 44.06 & 43.75 & \\
\hline & 0.575 & 40.25 & 40.93 & 160.53 & 9.05 & & 44.06 & 43.44 & \\
\hline
\end{tabular}


highest value of the compressive strength reached by the samples. If the cement was replaced by the fly-ash, the samples with $2 \%$ and $5 \%$ ash content reached higher compressive strength than the samples without the ashes.

For the mortars doped with the calcareous ashes, the compressive strength both after 28 and 56 days of curing was lower than for the mortars doped with the siliceous ashes. The tests performed after 28 days of curing showed that the mortars doped with $2 \%$ content of the calcareous ash reached the strength lower by $9.59 \mathrm{MPa}-$ it was equal $37.55 \mathrm{MPa}$. After 56 days the strength was lower by $14.22 \mathrm{MPa}$ than the strength for the mortar samples with the siliceous ash - it was equal $45.68 \mathrm{MPa}$. For the samples doped with 5\% of the ashes, the compressive strength was equal $39.11 \mathrm{MPa}$ after 28 days of curing and $45.68 \mathrm{MPa}$ after 56 days. For the samples doped with $10 \%$ of the calcareous ashes, the average value was equal $39.58 \mathrm{MPa}$ after 28 days of curing and $51.81 \mathrm{MPa}$ after 56 days. They were higher values of compressive strength. If the cement was replaced by the calcareous fly-ash, the compressive strength both after 28 and 56 days of curing was lower than the strength for the samples without admixtures.

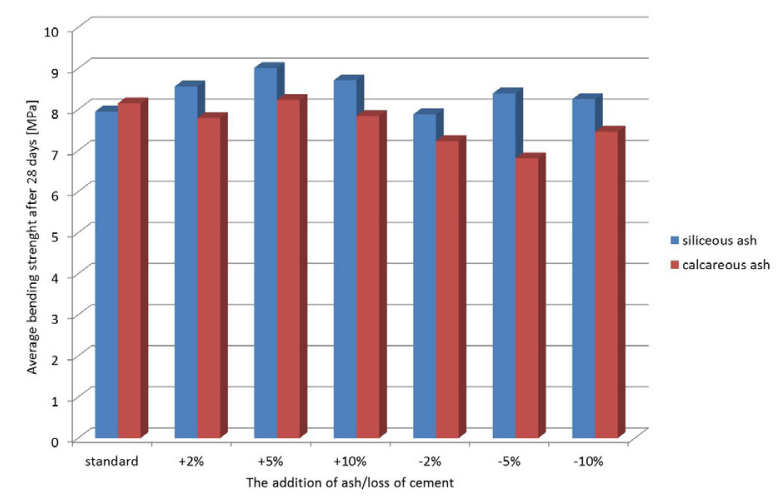

Figure 7. The average bending strength after 28 days

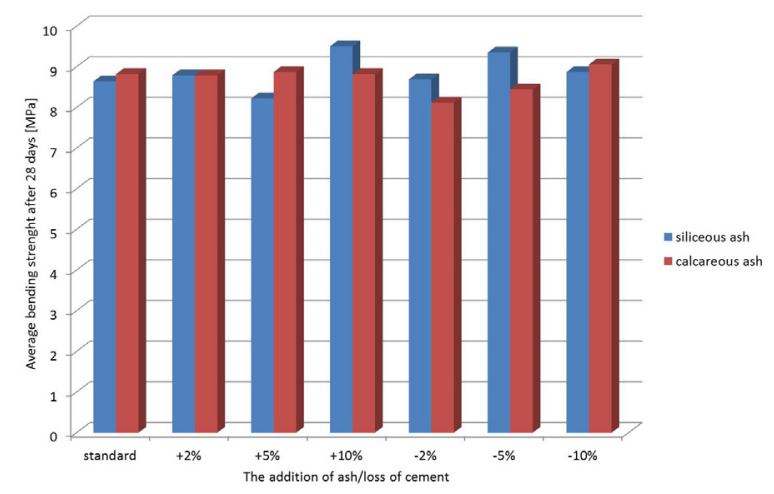

Figure 8. The average bending strength after 56 days
Figures 7 and 8 present the results of bending strength tests for the cement mortar samples. The tests were performed after 28 and 56 days of curing. The highest value of the bending strength after 56 days - equal to $9.35 \mathrm{MPa}$ - was reached by the samples where the $5 \%$ of cement was replaced by the siliceous ash. The lowest value equal 8.22 $\mathrm{MPa}$ - reached the mortar doped with the $5 \%$ ash content. The values of the bending strength reached by all of the samples after 28 days, felt in the range 7.88-9.01 MPa and after 28 days - in the range $8.22-9.35 \mathrm{MPa}$. The values of the bending strength for the mortars doped with the calcareous ash after 28 days of curing felt in the range 6.81-8.23 MPa and after 56 days all of the values increased and felt in the range 8.12-9.06 MPa. The highest value of the bending strength, equal to $9.06 \mathrm{MPa}$, was observed for the samples where the $10 \%$ of cement was replaced by the calcareous ash.

\section{ANALYSIS OF THE RESULTS OF THE PERFORMED TESTS}

The tests of several cement mortars containing the admixture of siliceous and calcareous ash in quantity of 2,5 and $10 \%$ of cement mass (the ash as an additional ingredient and as a cement substitute) were performed.

The influence of ashes was evaluated on the basis of the results of the tests performed for the cement mortars (tests of compressive and bending strength after 28 and 56 days of curing). The ash admixture had smaller or greater influence on each of the tested features. The compressive strength tests of the cement mortars showed that the increasing ash content positively affects the compressive strength - the higher ash content the higher compressive strength. If the cement was replaced by the ash, the compressive strength decreased along with the increase of the ash quantity. In the compressive strength tests performed after 28 and 56 days, the strength increase was observed along with the concrete curing time. The strength of the mortars with the siliceous ash admixture was higher than of the mortars with the calcareous ash admixture.

The bending strength for the mortars with the siliceous ash admixture was higher than this of the samples with the calcareous ash admixture. Moreover, the tests showed that along with the increase of the ash content till 5\% (the ash 
added and replaced) the value of the strength increases, whereas if the content is equal $10 \%$, the strength decreases.

\section{CONCLUSIONS}

The application of fly-ashes in production of cement mortar has significant ecological and economic advantages: it causes reduction in emission of carbon dioxide, optimization of cement consumption, savings of raw materials and consumption of combustion by-products. Basing on the performed investigations, the following conclusions have been put forward:

1. The admixture of siliceous and calcareous flyash affects the mechanical properties of cement mortars.

2. The compressive strength increase for the mortars with the siliceous fly-ash admixture in comparison with the mortars with the calcareous fly-ash was observed.

3. It was established that along with the concrete curing time the compressive strength of the mortars with the siliceous and calcareous ash increases. However, it does not exceed the values for the unmodified mortar and the mortar with the cement replaced by fly-ashes.

4. Basing on the bending strength tests, it was established that the highest value of this strength was reached by the mortar with the $10 \%$ admixture of siliceous ash.

5. It was observed that from among the fly-ash admixtures being applied the siliceous ash admixture improves the bending strength of the mortars made of the cement doped in such way.

\section{REFERENCES}

1. ACI Committee 232, Use of fly ash in concrete. ACI committee report 232. 2R-96. ACI, April 1996.

2. Alonso J.L., Wesche K., 1991. Characterization of fly ash. Fly ash in concrete properties and performance. Report of technical committee 67-FAB- use fly ash in building. Rilem (K. Wesche ed.) E\&FN Spon.

3. Comões A., 2002. High performance concrete incorporating fly ash. PhD Thesis, University of Minnho.
4. Deja J., Antosiak B., 2012. Degree of progress of the fly ash reaction in alkali-activated fly-ash binders. Cement Wapno Beto, marzec-kwiecień.

5. Elahi A. et al. 2010. Mechanical and durability properties of high performance concretes containing supplementary materials. Constr. Build. Mat. 24, 292-299.

6. Giergiczny Z., 2007. Fly ash properties and durability of concrete (in Polish). Budownictwo Technologie, Architektura, 3 (39), 44-49.

7. Giergiczny Z. 2013. Popiół lotny w składzie cementu i betonu (Fly-ashes in composition of cement and concrete). Wydawnictwo Politechniki Śląskiej, Gliwice.

8. Golec T., Remiszewski K., Świątkowski B., Błesznowski M., 2007. Palniki pyłowe na biomasę (Biomass powdered-fuel burners). Energetyka i Ekologia, 5.

9. Joshi R.C., Lohtia R.P. 1997. Fly ash in concrete: production properties and uses. Advances and Concrete Technology (V.M. Malhot ed.) Vol. 2, Gordon and Breach Science Publishers, p. 269, Ottawa Ontario, Canada.

10. Malhotra V.M., Ramezanianpour A.A., Fly ash in concrete. 2nd edition, CANMT- Canada Centre for Mineral and Energy Technology.

11. Rutkowska G., Małuszyńska I., 2014. Investigations of properties of concrete produced with admixtures of fly-ashes (in Polish). Inżynieria Ekologiczna, 36.

12. Rutkowska G., Wiśniewski K., i in. 2016. Influence of fly-ashes on properties of ordinary concretes. Annales of Warsaw University of Life Sciences - SGGW.

13. Rosik-Dulewska Cz., Karwaczyńska U., 2008. Methods of leaching of impurities in mineral waste from the point of view of its application in hydrotechnical engineering (in Polish). Rocznik Ochrony Środowiska, 10.

14. Wesche K., 1991. Fly ash in concrete; properties and performance. Report of technical committee 67 - FAB- use of fly ash in building. Rilem (K. Wesche ed.) E\&FN Spon.

15. PN-B 14501 - 1990. Ordinary building mortars (in Polish).

16. PN-EN 1015-11:2001. Methods of test for mortar for masonry. Determination of flexural strength and compressive strength of the hardened mortar (in Polish).

17. Investigation report No. $721 / 2014$. 